\title{
Green DIY store choice among socially responsible consumer generations
}

\author{
Dan-Cristian Dabija * (D) and Brandusa Mariana Bejan
}

\begin{abstract}
The purpose of our empirical investigation, based on the theory of reasoned action and generational theory, is to study the green DIY retail store choice of socially responsible consumer generations (Baby Boomers, Millennials, Gen X-ers and Gen Zs). The authors base their quantitative research on structural equation modelling in an emerging market (Romania) to highlight the socially responsible consumption behavioural factors (education on environmental protection and social responsibility, rational use of resources and financial sacrifice necessary to protect the environment) which drive the customers of international DIY store chains operating in Europe in their choice of retail formats. The results reveal that there is a difference between Romanian and European-based retail chains with respect to the impact of socially responsible consumption behavioural dimensions on the choice of retail format, due to their respective communication of environmental governance strategies and different actions implemented. The research contributes to the development of the literature by establishing a connection between socially responsible consumption behaviour and retail format choice in green DIY retailing. From the management perspective, the paper provides retailers operating in emerging markets with possible directions to adapt their strategies when approaching these markets. The value of the paper lies in the application of socially responsible consumption behaviour scale and generational theory in green DIY retailing to a fast-growing emerging market, with a view to enhancing consumer retail format choice, depending on their attitudes towards social responsibility and propensity towards environmental protection.
\end{abstract}

Keywords: Socially responsible consumption behaviour, Socially responsible consumers, DIY retailing, Green DIY, Emerging market, Green consumers, Green retail stores

JEL codes: M31, M11, Q55

\section{Introduction}

Social responsibility is increasing in importance and relevance for organizations striving to gain competitive strategy and planning to target consumer segments (Pryshlakivsky and Searcy, 2015). By adopting precise actions aimed at protecting the environment, reducing pollution and/or the consumption of resources and raw materials, designing green products, services and brands, and showing concern for employees and customers, as well as for the local communities where production, processing and distribution units exist (Dabija and Băbuț, 2013; Dabija and Pop, 2013; Dabija and Bejan, 2017) retailers are striving to improve their image and attractiveness among consumers of different ages. Social responsibility has increasingly become a key

\footnotetext{
* Correspondence: cristian.dabija@econ.ubbcluj.ro

Faculty of Economics and Business Administration, Department of Marketing, Babeș-Bolyai University Cluj-Napoca, Cluj-Napoca, Romania
}

plank of retailers' strategic orientation, being consistently pursued and put into practice by the management.

By embracing social responsibility, sustainable principles and environmental governance, retailers have been able to boost customer trust and acceptance, reaping the benefits from their satisfaction with products and services, and gaining their loyalty (Dabija et al., 2014; Dabija, 2018). The offer of green products adjusted to consumers' new socially responsible consumption behaviour has enabled retailers to take advantage of the upward trend and adapt accordingly. Depending on the consumer generations targeted, retailers have been faced with significant gaps between the individual's motivations, beliefs, expectations and buying reasons, and the way in which these aspects can turn into actual purchases. Retailers need to ensure that customers' motives and preferences translate into buying decisions, determining their behaviour. However, little is known about how 
consumers of different generations act, and how they make purchasing decisions depending on the extent to which European DIY retail stores implement social responsibility in emerging markets by implementing specific measures, such as protecting the environment, reducing pollution, reducing the consumption of resources, etc.

Previous studies have found major influences of green oriented fashion retailers among consumer generations (Dabija et al., 2017; Dabija, 2018), however little is known about DIY retail. We have relied on the socially responsible consumption behaviour scale proposed by Antil and Bennet (1979) and Antil (1984) in order to investigate green DIY store choice in an emerging market. We have chosen to base the investigation on the Romanian market because it is among those showing the fastest growth of GDP in recent years (Obucina, 2017).

Our investigation drew on the reasoned action theory formulated by Ajzen and Fishbein (1980), based on the premise that an individual's behaviour may lead to a specific result (Madden et al., 1992). Retailers aim to stir up in consumers a purchase intention which, in most cases, translates into the purchases expected. The theory of reasoned action takes into account consumers' attitudes, thereby making reference to their subjectivity (Nadlifatin et al., 2016). Retailers must consider the impact of the affective component on the formation of an attitude and its translation into an actual purchase. There are significant differences across generations. For instance, with Millennials, retailers have to consider their financial resources, together with the influence of friends (Dabija and Bejan, 2017). Wishing to be accepted by their reference group, individuals may conceal their behaviour and choose to purchase items preferred by peers. The paper also draws on the generational theory according to which each generation of consumers can be clearly defined as an independent target segment which can be properly approached by retailers with a strategy specifically tailored to their characteristics, motives, preferences and attitudes (Codrington, 2008; Meriac et al., 2010).

The paper is structured into five sections. Section One deals with sustainability and its role in persuading people to embrace socially responsible behaviour and a favourable attitude towards environmental protection. It discusses how this phenomenon is connected to, and influenced by the generations of consumers. The next section concerns DIY retailers and highlights some of the specific social responsibility actions carried out to attract consumers of different ages. The third section presents the research methodology and proposed analysis model, while Section Four approaches the format choice behaviour of consumer generations and the driving factors for each individual generation concerned. The paper ends with the conclusions, research limitations and prospects, together with managerial and theoretical implications.

\section{Social responsibility and sustainability}

The initial purpose of applying the principles of sustainability within their general business strategy was for organizations to gain a competitive advantage on targeted markets (Hubbard, 2009). As society progressed, and pollution, along with large-scale exploitation of resources to the point of depletion became increasingly widespread, retailers' managers started to understand the necessity of embracing the principles of sustainability into their business strategies and to put them into practice by means of social responsibility. However, these might have led to the risk of no longer generating competitive advantage, with markets tending to lose trust in stores that failed to take concrete steps and measures in this respect. For many managers, sustainability entailed additional costs that had to be kept to a minimum. In recent years, managers have started to recognize the importance of social responsibility actions within the general business strategy. These "compliance issues" (Hubbard, 2009) usually pertain to environmental protection activities, responsibility towards local communities, care of "internal customers", etc.

The concept of sustainability and its related principles were recently re-analysed and incorporated into the new phrase "corporate sustainability management" (Schuler et al., 2017). Corporate sustainability management considers the demands and expectations of consumers, employees and partners of organizations, and establishes a correlation between these stakeholders' activities and aspects influencing the environment. "Corporate sustainability management" has proven quite difficult to embrace, because of decision-makers' reluctance to make changes, and the need to identify appropriate ways of putting it into practice (Mulder, 2017). Employees must be trained regarding sustainability and social responsibility and how these principles can be correlated with the expectations of communities and society at large where retailers operate. Marketing-oriented organizations are willing to better satisfy customers' needs (Green et al., 2015) because they have the know-how and the capacity to collect information about target segments; they also have the resources to identify swiftly and effectively the changes in customer behaviour and make the needed adjustments accordingly. Acting in line with the principles of the new "corporate sustainability management", companies seek to redefine and restructure their offering by including green and environmentally friendly products and services (Baumgartner and Rauter, 2016).

\section{Social responsible consumption behaviour}

A half-century ago, the annual consumption of commodities was lower than nature's capacity to regenerate them in 365 days. The recent population explosion has fostered an exponential growth in the worldwide consumption of commodities, so that it now takes the Earth one year and six months to regenerate the resources mankind consumes in 
a single year (Lakshmi and Kennedy, 2017; Resurse Terra, 2017). In order to hold back this phenomenon, reduce carbon dioxide emissions and prevent the exploitation of natural resources (water, plants, animals, etc.) governments and organizations must come up with viable solutions, and people must change their behaviour by adopting a new type of consumption oriented towards green products and services made from renewable resources and with an impact on nature as minimal as possible (Dabija, 2018).

Sustainable consumption behaviour becomes an essential goal for companies, and should be included in a holistic approach to their general business strategies (Dermody et al,, 2015; Singh and Sharma, 2016). The penchant for sustainable consumption behaviour depends on an individual's orientation and his or her values, as well as on a country's level of development. Orientation towards materialism and behavioural antecedents are reflected in the individual's values and subsequent behaviour. Care for the environment and the motivation to adopt responsible consumption together lead to sustainable consumption behaviour (Dermody et al., 2015). Socially responsible consumption is based on the idea that consumers prioritize their purchasing decisions and tend to buy products from producers and retailers that adopt sustainability principles, and implement strategies and policies that pay increased attention to social responsibility and environmental protection (Ulusoy, 2016). Among such actions implemented by retailers we may note: the use of certified raw materials, launching social responsibility campaigns, prioritizing the establishment of partnerships with companies that comply with sustainability principles, replacing packaging and training consumers on how to recycle it, etc. (Bekele et al., 2012). This is how sustainability strategy and actions designed to support socially responsible consumption helps to attract as many customers as possible.

Consumption may be related to the waste or destruction of resources, sometimes leading environmental devastation (Singh and Sharma, 2016). Managers are faced with new challenges, having to adopt strategies able to discourage the measures that might have negative and irreversible effects on the environment and on the society. Proactive behaviour can be supported by carrying out social responsibility actions (Romani et al., 2016), regardless of the company's field(s) of activity. As the negative effects of pollution have become more and more widespread, organizations have conducted social responsibility campaigns aimed at customers, business partners (suppliers, distributors etc.) and their own employees, and have taken measures to make people more responsible towards the consumption of resources, materials as well as products and services (Bekele et al., 2012; Tuten, 2013; Bear, 2017).

Sustainable consumption is often associated with the purchase of green and/or organic products (Biswas and Roy, 2015). Consumers adopting sustainable purchasing behaviour prefer such products and are willing to pay a price-premium for them (Tuten, 2013). What accounts for the higher price is the higher cost of production so as not pose a danger to the environment (Shobeiri et al., 2016). $61 \%$ of consumers are willing to pay a $5 \%$ higher price to purchase green products (Lim, 2017). Retailers also promote green products within their communication strategies aimed at educating and informing consumers about the characteristics and advantages of such products, as well as the recycling and of eco-friendly, reusable packages or packages made of reused materials (Tuten, 2013; Tariq, 2014). As soon as customers become aware of these aspects, they focus their attention on retailers that promote such behaviour. Green marketing has a more profound significance based on the premise that retailers have to develop and maintain sustainable relationships with all stakeholders, particularly with customers, always protect the environment and act responsible. When retailers comply with these norms, they help target groups develop sustainable behaviour (Rettie et al., 2012).

The purchase of sustainable products is based on trust in retailers and on their ability to "convince" consumers of their characteristics and benefits. As customers are unable to check the potential chemical substances in the composition of goods, the label "organic product" simply reflects their quality (Nuttavuthisit and Thøgersen, 2015). Retailers have to make good on their promises at the time of consumption or usage their products should even exceed what was promised - so that customers' expectations may be properly satisfied. Retailer reputation plays a special role in building customer trust, together with the opinions of peers and the individual's previous experiences (Laroche and Bergeron, 2001). If existing collaboration between a consumer and a retailer over its brands has yielded a positive experience to the effect that the purchased products meet or even exceed his/her expectations, the consumer will buy green products with confidence, even if this is a new experience for them (Silva Braga et al., 2015).

\section{Consumers' attitudes towards social responsibility and environmental protection}

Consumers prove their concern for social responsibility and the environment by the products they purchase and the retail chains they prefer, in particular those that apply the principles of sustainability (Schmidt et al., 2012; Joshi and Rahman, 2015). Despite customers' increasingly strong preference for green, and sustainable products made in compliance with environmental protection and social responsibility principles (Li et al., 2016), recent studies show an interesting paradox: these products attract custom, but the revenue that retailers gain from this segment is not significant (Lim, 2017). From an attitudinal viewpoint, consumers lack the conative component which prompts them to actually buy green products. Aschemann-Witzel and 
Zielke (2017) believe that price is the main obstacle to the completion of the purchasing process for such consumers. Although they are conscious of the added value of green products, they refrain from actually purchasing them due to the financial sacrifice they would have to make. The higher price of green products is also the result of the higher costs producers have to bear. Although the global number of organic agricultural products has tripled in the last decade, the area planted with such products accounts for less than $1 \%$ of all agricultural land (Aschemann-Witzel and Zielke, 2017), which favours keeping final selling prices at high levels.

It often happens that products of DIY retail go for a high price. Two factors account for this: (1) some retail chains have collaboration with local producers and the added value of the sold goods goes to the communities at a local level, and (2) various specific norms and standards must be complied with during their production regarding pollution, reduction of PM emissions in the air, making goods that do not harm the environment or the communities, etc. (Ayadi and Lapeyre, 2016). Since DIY products are mostly made from natural components such as wood or wood derivatives, retailers will have initiated or been actively involved in social responsibility campaigns (Gurtoo et al., 2010). Actions undertaken include the afforestation of cleared lands, cleaning up green and other areas, supporting communities through specific social and/or environmental protection programmes, etc. (Elg and Hultman, 2011).

Individuals' exhibiting sustainable behaviour depends on how much they are interested in complying with social responsibility and on the extent to which they are aware of the impact they have on the environment (Galbreth and Ghosh, 2012). Care for the environment varies across individuals according to their education, the generation to which they belong and the lifestyle they adopt. The information customers get about the characteristics of eco-friendly products helps them develop the cognitive component of attitudes, while the responsibility towards the environment is fostered by the affective component (Silva Braga et al., 2015). Both components help the development of sustainable behaviour that translates into the actual purchase of products that meet social responsible criteria.

From an attitudinal perspective, individuals are swifter to form an opinion about companies that pay attention to the environment and integrate social responsibility issues within their general business strategy. Their increased purchasing frequency and the number of goods purchased from such companies are a reflection of their loyal behaviour (Lin et al., 2017). Seeing this opportunity, many companies have integrated social responsibility and environmental protection campaigns within their general business strategy, and adopted proactive behaviour towards the communities in which they operate (French and Showers,
2008) by providing brands, products and services made in compliance with these principles. In a similar vein, retailers have shown an increasing tendency to promote social issues and values in their relationships with customers, seeking to gain their trust through green offers adjusted to the expectations of these target segments.

\section{Consumer generations' orientation towards social responsibility}

Despite the heterogeneous characteristics of each generation of consumers, they have specific needs and desires on which they place great importance and seek to satisfy by purchasing particular goods and services (Chu et al., 2013). Retailers are compelled to identify those aspects that influence the buying decision and the stimuli that shape individuals' perception of a particular product or brand so as to integrate them within their business strategies. It is difficult to provide green products and services made of components complying with environmental and social responsibility norms and regulations and meeting the established sustainability objectives, because each generation of consumers has a different approach to these values. In fact, the gaps between the generations of consumers in terms of green behaviour and green consumption patterns are more and more obvious. Studies show that, from a social responsibility perspective, Baby Boomers and Millennials exhibit similar behaviour, that of concern for environmental protection, albeit for different reasons. Baby Boomers want to live in a clean environment, as a "reward" for their lifelong work for the benefit of society, and because they want to bequeath a clean environment to future generations, their grandchildren (Millennials) and great-grandchildren (Generation Z) (Boschini, 2015). Millennials believe they can use natural resources to earn their desired lifestyle without jeopardizing the lifestyle of future generations (Boschini, 2015). Although there is some commonality between both generations, Baby Boomers are more reluctant to buy green products because of the higher prices charged, as they do not always have the necessary money. Millennials face a similar situation. Being at an early stage of their careers, they may also have modest incomes, but express great care for nature, the environment and for others (Zahari and Esa, 2016). Millennials may exhibit polyvalent behaviour, failing to put into practice their "statements" about green behaviour and green consumption. They often change their opinions and buy other products, depending on the stimuli to which they are exposed and the influence of social media (Dabija et al., 2018).

By contrast, Gen Xers are more pragmatic and realistic, being eager to obtain tangible results, a fact which influences their personal beliefs (Honeywell and Pease, 2014). Gen Xers form their opinions on the basis of expected results and on how likely it is for these to be achieved. Therefore, their ideals are a lot less lofty, focusing mostly 
on the tangible facets of life. Numerically, there are fewer Gen Xers than Millennials, with only 41 million people worldwide (Taken Smith, 2014).

According to population size, Millennials represent a target segment consisting of over 80 million people (Taken Smith, 2014). Companies often conduct specific research to better understand Millennials' characteristics, values, preferences, motives, attitudes and behaviour, hoping to identify appropriate levers to draw their attention, provide them with information and have them buy their products (Hill Hyun-Hwa Lee, 2012). Millennials have a preference for social responsible products and brands which have a positive impact on the environment, the production of which does not have harmful effects or a negative influence on nature (Chu et al., 2013). Being aware of the potential represented by this customer segment, retailers try to please them by means of green communication advertising and messages (Taken Smith, 2014). By following this strategy, retailers have been able to activate the conative component of consumers' attitudes, making them purchase green products. Millennials are attracted by catchwords such as "ecofriendly", "green", "social responsible" or "recycled" accompanying the promotion of sustainable products (Smith, 2010). The use of these catchwords on packaging, as part of communication strategies and actions, have boosted product marketing and sales, leading to greater revenues for companies (Taken Smith, 2014). Unlike Millennials, Gen Xers are easier to "target" by means of advertisements, as they allow themselves to be more easily influenced by other people (Acar, 2014). Being pragmatic in character, they make decisions with full knowledge of the facts and information about products, services, brands, etc., often coming from members of the reference groups to which they belong or identify themselves with.

\section{Social responsibility in DIY retail}

DIY retailers are paying increased attention, at both a national and international level, to principles related to social responsibility and local community involvement, environmental protection, pollution reduction, and adjusting their business strategies accordingly. A European- based DIY retailer, IKEA is offering its customers bags made from recyclable materials for carrying small products. All of its stores use LED bulbs, $40 \%$ of them having solar panels which absorb sunlight as a source of energy. Over 70 wind turbines produce its electrical energy, while geothermal energy is used in nine countries. In partnership with the Forest Stewardship Council, Jysk, another European DIY retailer, advocates the protection of forests, because wood represents the most important raw material for producing its marketed furniture. Jysk is taking part in forest restoration actions by providing foresters with special equipment and helping to improve their working conditions. The retailer is also concerned with reducing carbon dioxide emissions, the heating systems of Jysk stores being so designed as to heat smaller areas than the systems of other retailers (Dabija et al., 2017).

A third European retailer, Praktiker encourages its customers to recycle WEEE. The retailer has created in-store "green corners" where the electric, electronic and household appliances are collected. There are two partners, Rorec and Recolamp, with which the retailer cooperates (Praktiker.ro, 2015). Wishing to provide future generations with a clean environment and to minimize the negative impact of its expansion, Dedeman, a Romanian-based DIY retailer, sponsored the campaign "We plant good deeds in Romania" by means of which over 300,000 trees were planted (Dedeman, 2016; Dabija et al., 2017). In 2016, the Romanian Ambient DIY retail chain took the first measures aimed at the reforestation of illegally cleared areas. Similarly, during the winter holidays customers were encouraged to purchase potted Christmas trees so that they may later be replanted. The European DIY retail chain, Leroy Merlin stores aim to reduce pollution, by working towards reducing the consumption of water, energy and paper. Some of these stores already have the Haute Qualité Environnementale certificate (Dabija et al., 2017).

\section{Research methodology}

In order to assess the preference for green European DIY stores of four consumer generations (Baby Boomers, Gen Xers, Millennials and Gen Zers) depending on the penchant for social responsibility and environmental protection, the authors have conducted a quantitative research on an emerging market. In that regard, they propose to study the relationships presented in Fig. 1.

Respondents of various ages were asked to fill in a questionnaire administered by volunteers at their homes, work/study places and in public areas (parks, promenades, streets, etc.). The volunteers were students of the authors, aged between 20 and 24 years. They could choose any respondent, so long as the sampling plan was respected. The sampling was based on quotas set for gender and age, benchmarked against Romania's latest Statistical Yearbook (2014). After the data collection, respondents were divided by the authors according to the generational theory (Williams and Page, 2011) and their year of birth in the proper generation: Baby Boomers if they were born between 1946 and 1964 (Katz, 2017), Gen Xers (born between 1965 and 1979) (Katz, 2017), Millennials (born between 1980 and 1994)

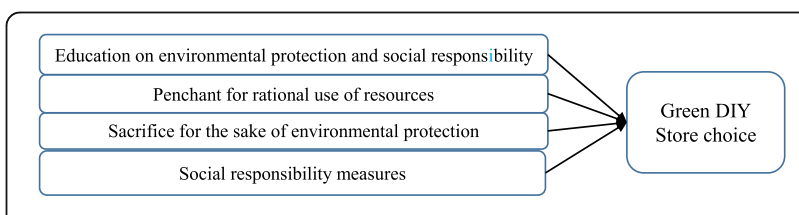

Fig. 1 The investigated model. Source: own research 
(Cordeiro and de Albuquerque, 2017) and Generation Z (born after 1995) (Desai and Lele, 2017).

The concepts from Fig. 1 were operationalized in accordance with the literature (see Table 1). In this respect, we made use of the socially responsible consumption behaviour scale (SCRB) proposed by Antil and Bennet (1979) and Antil (1984). Respondents' level of agreement in relation to their favourite European-based DIY retailers was expressed on a five-point Likert scale. Data validity, reliability and internal consistency were tested for all dimensions concerned (education on environmental protection and social responsibility, penchant for rational use of resources, financial sacrifice needed to protect nature, social responsibility measures, green European-based DIY stores choice) with the help of Cronbach Alpha, Item-to-total Correlation, Exploratory Factor Analysis. Each value exceeded the minimum acceptable levels laid down (Churchill, 1991).

Combining all items into a single exploratory factor analysis allowed a clear delineation of the four dimensions presented in Table 2 in the order of their extraction. As the dimensions were found to be individually stable, they were subsequently included in a confirmatory factor analysis with AMOS (Table 4).

\section{Results}

\section{Sample description}

The 744 valid questionnaires contained Romanian respondents' assessment of various DIY retail stores belonging to national chains, such as Ambient, Casa Rusu, Dedeman, Denver, Elvila, King Art, Lems, Mobexpert, Nobila Casa, and international chains such as Leroy Merlin, Bricostore, Hornbach, IKEA, Jysk, Metro, Praktiker. These European-based DIY retail chains had operated in the Romanian market for more than 15 years, and were well-known to the respondents (Dabija and Abrudan, 2015). The breakdown of respondents by gender was approximately uniform, in accordance with the latest data used for sampling, taken from Romania's Statistical Yearbook (2014) (Table 3). There were 104 Baby Boomers (14\% of the sample), 195 Gen Xers (15.9\% of the sample), 291 Millennials (39.1\%) and 154 members of Generation Z (20.7\%). There was a relatively even distribution among generations, with Millennials being slightly over-represented because it was easier for the interviewers to contact people of similar age, while some questionnaires were discarded because they had too many missing data (Churchill, 1991; Marsh, 1998) (Table 3). Literature suggests that for structural equations modelling, each category should consist of at least 50 cases/responses (Homburg and Krohmer, 2006, p.225); however having more items in each category should ease data analysis (Aaker, et al., 2000, p.24).

Respondents' behaviour varied when it came to the frequency with which they visited the assessed DIY stores. Millennials visited DIY stores most often (7.9\%), followed by Gen Xers (5.4\%), while many Baby Boomers (6.9\%) and Zers $(10.4 \%)$ visited them once a year or less. DIY stores were visited several times a year by Millennials (16.8\%) and Gen Xers (10.6\%), which leads to the conclusion that members of these two generations either build their own houses or decorate them and, consequently, purchase more frequently from DIY retailers. These findings are similar to previous studies (Gurtoo et al., 2010).

\section{Results on generations}

The analysis of generations shows that the general model on 744 cases, as well as the multi-group analysis for each generation was stable, their fit indices falling within the imposed limits (Forza and Filippini, 1998; Ju et al., 2006). European-based DIY store choice of environmental and social responsible oriented retailers was directly and significantly influenced by the penchant for rational use of resources $(0.180 \%)$, the (financial) sacrifice necessary to protect the environment $\left(0.262^{* * * * *}\right)$ and by social responsibility measures $\left(0.210^{* * * *)}\right)$. Education on environmental protection and social responsibility $\left(0.153^{\text {n.s. }}\right)$ did not have a significant impact for the 744 cases of respondents' green DIY retail format choice (Table 4).

For the 744 cases, the financial sacrifice respondents were willing to make $\left(0.262^{* * * * *}\right)$ contributed most to their choice of green DIY stores. Respondents were aware that they could not purchase products which contribute to environmental protection and which are socially responsible without financial implications (in the form of a sacrifice). A less

Table 1 Results of testing validity and reliability of collected data

\begin{tabular}{lllllll}
\hline Dimension & Items & $\mathrm{a}^{\mathrm{a}}>0,7$ & $\mathrm{KMO}^{\mathrm{b}}>0,7$ & $\mathrm{X}^{2} ; \mathrm{df} ; \mathrm{p}^{\mathrm{c}}$ & Eigenvalue & $\%$ variance \\
\hline Education on environmental protection and social responsibility & 6 & 0.899 & 0.874 & $2168.58 ; 10 ; * * *$ & 3.564 & 71.28 \\
Penchant for rational use of resources & 5 & 0.852 & 0.884 & $1818.007 ; 21 ; * * * *$ & 3.717 & 53.10 \\
Sacrifice for the sake of environmental protection & 3 & 0.758 & 0.763 & $692.194 ; 6 ; * * *$ & 2.316 & 57.91 \\
Social responsibility measures & 3 & 0.849 & 0.879 & $1874.200 ; 21 ; * * * *$ & 3.708 & 52.97 \\
Green DIY store choice & 5 & 0.921 & 0.821 & $1981.211 ; 32 ; * * * * 3.324$ & 61.43 \\
\hline
\end{tabular}

${ }^{a}$ Cronbach's a coefficient (checking data reliability)

${ }^{b}$ Kaiser-Meyer-Ohlin criterion (exploratory factor analysis) for each dimension

'Bartlett's test of sphericity ( $x^{2}-$ hi square, df - degrees of freedom, $p$ - probability; $\left.{ }^{* * *} p<0,001 ;{ }^{* * *} p<0,01 ; *^{* *} p<0,05 ;{ }^{*} p<0,1\right)$

Source: own research 
Table 2 Factor analysis of the investigated dimensions

\begin{tabular}{|c|c|c|c|}
\hline Construct (References) & Items & Loa-dings & FIT \\
\hline \multirow[t]{6}{*}{$\begin{array}{l}\text { Education on environmental protection and social } \\
\text { responsibility (EEP) (Antil and Bennett, 1979; Antil, 1984) }\end{array}$} & $\begin{array}{l}\text { I get angry when I think about the ways in which industry pollutes } \\
\text { the environment. }\end{array}$ & 0.817 & \multirow{6}{*}{$\begin{array}{l}\text { EV: } 3.24 ; \\
\% \text { of var.: } \\
31.2\end{array}$} \\
\hline & $\begin{array}{l}\text { Schools should require that all students attend a course on social } \\
\text { responsibility, environmental and nature conservation issues. }\end{array}$ & 0.654 & \\
\hline & $\begin{array}{l}\text { I am willing not to buy any more products from retailers that are } \\
\text { guilty of environmental pollution and are not social responsible. }\end{array}$ & 0.601 & \\
\hline & $\begin{array}{l}\text { I become angry when thinking about the negative impact of } \\
\text { pollution on plants and animals. }\end{array}$ & 0.589 & \\
\hline & $\begin{array}{l}\text { I am willing to make sacrifices to reduce environmental pollution } \\
\text { even if the immediate results do not appear significant. }\end{array}$ & 0.511 & \\
\hline & $\begin{array}{l}\text { People should limit the use of products obtained from scarce } \\
\text { resources. }\end{array}$ & 0.403 & \\
\hline \multirow{5}{*}{$\begin{array}{l}\text { Penchant for rational use of resources (PRUR) } \\
\text { (Antil and Bennett, 1979; Antil, 1984) }\end{array}$} & Our efforts to save the limited, exhausted resources are not enough. & 0.828 & \multirow{5}{*}{$\begin{array}{l}\text { EV: } 2.12 ; \\
\% \text { of var.: } \\
26.4\end{array}$} \\
\hline & $\begin{array}{l}\text { Producers are not sufficiently encouraged to use recyclable } \\
\text { packaging. }\end{array}$ & 0.687 & \\
\hline & Pollution is now one of the most sensitive issues of our nation. & 0.557 & \\
\hline & $\begin{array}{l}\text { Natural resources must be preserved even at the cost of giving up } \\
\text { some goods or services. }\end{array}$ & 0.459 & \\
\hline & $\begin{array}{l}\text { People should be concerned about the impact of their articles on } \\
\text { the environment. }\end{array}$ & 0.406 & \\
\hline \multirow[t]{3}{*}{$\begin{array}{l}\text { Sacrifice for the sake of environmental protection } \\
\text { (SPE) (Antil and Bennett, 1979) }\end{array}$} & $\begin{array}{l}\text { I agree to have my taxes increased by } 5 \% \text { if this enables a more } \\
\text { rigorous control of pollution by the government. }\end{array}$ & 0.769 & \multirow{3}{*}{$\begin{array}{l}\text { EV: } 1.95 ; \\
\% \text { of var: } \\
23.7\end{array}$} \\
\hline & $\begin{array}{l}\text { I am willing to increase my total family expenses by } 100 \text { EURO next } \\
\text { year in order to support the rational use of natural resources. }\end{array}$ & 0.606 & \\
\hline & $\begin{array}{l}\text { I would be willing to donate my salary for a full day to a foundation } \\
\text { in order to help improve the environment. }\end{array}$ & 0.521 & \\
\hline \multirow[t]{3}{*}{ Social responsibility measures (SRM) (Antil, 1984) } & $\begin{array}{l}\text { Producers should be compelled to use recycled materials during } \\
\text { production and/or processing. }\end{array}$ & -0.612 & \multirow{3}{*}{$\begin{array}{l}\text { EV: } 1.21 ; \\
\% \text { of var.: } \\
18.7\end{array}$} \\
\hline & $\begin{array}{l}\text { I would accept my stuff being less white or elegant to make sure I } \\
\text { have used a non-polluting detergent. }\end{array}$ & -0.556 & \\
\hline & $\begin{array}{l}\text { People should persuade their friends not to use products that } \\
\text { pollute or are not socially responsible. }\end{array}$ & -0.467 & \\
\hline \multirow[t]{5}{*}{ Store Choice (SC) (Nasir and Karakaya, 2014) } & I intend to buy "green" DIY articles in the next three months. & 0.743 & \multirow{5}{*}{$\begin{array}{l}\text { EV: 1.18; } \\
\text { \% of var. } \\
15.4\end{array}$} \\
\hline & I will recommend "green" DIY stores to my friends and relatives. & 0.721 & \\
\hline & I will buy more "green" DIY articles in the future. & 0.702 & \\
\hline & $\begin{array}{l}\text { In the near future I will try out other types of "green" DIY articles } \\
\text { which I have not bought before. }\end{array}$ & 0.689 & \\
\hline & $\begin{array}{l}\text { If the needed "green" DIY articles are not available in the store, I will } \\
\text { look for them in other stores even if these are far away. }\end{array}$ & 0.642 & \\
\hline
\end{tabular}

Obs.: EV: Eigenvalues for each factor; \% of variance: percent of variance for each factor; Extraction Method: Principal Axis Factoring. Rotation Method: Oblimin with Kaiser Normalization. Rotation converged in 12 iterations

Source: own research

strong, but highly significant correlation was found with social responsibility measures $\left(0.210^{* * *}\right)$. Among such measures was the need for producers to use recycled materials that take on a new form in as many marketed goods as possible, the care for local communities, as well as the use of commodities with a lower impact on the environment. All consumers seemed to be aware of the responsibility they have to protect the environment. The need to save resources and raw materials, in both production and distribution processes, the use of recycling and environmentally-friendly packaging, the general reduction of pollution, and a drop in the consumption of certain goods and services so as to achieve the general goal of protecting the environment represented an important aspect for all generations of consumers, but of less strength and significance $(0.180 * *)$. The most unusual result for the whole sample was the lack of significance of "education on environmental protection and social responsibility". Although respondents seemed to understand the need to protect the environment, reduce the consumption of goods 
Table 3 Socio-demographic characteristics of the sample

\begin{tabular}{|c|c|c|c|c|c|c|c|c|c|c|}
\hline \multirow[t]{2}{*}{ Generations } & \multicolumn{2}{|c|}{ Baby Boomers } & \multicolumn{2}{|c|}{ Generation X } & \multicolumn{2}{|c|}{ Millennials $/ Y$} & \multicolumn{2}{|c|}{ Generation Z } & \multicolumn{2}{|l|}{ Total } \\
\hline & $n$ & $\%$ & $n$ & $\%$ & $n$ & $\%$ & $n$ & $\%$ & $n$ & $\%$ \\
\hline \multicolumn{11}{|l|}{ Gen } \\
\hline Male & 53 & 7.1 & 77 & 10.3 & 163 & 21.9 & 81 & 10.9 & 374 & 50.3 \\
\hline Female & 51 & 6.9 & 118 & 15.9 & 128 & 17.2 & 73 & 9.8 & 370 & 49.7 \\
\hline Total & 104 & 14.0 & 195 & 26.2 & 291 & 39.1 & 154 & 20.7 & 744 & 100.0 \\
\hline \multicolumn{11}{|l|}{ DIY store frequency visit } \\
\hline Once a year or less & 51 & 6.9 & 75 & 10.1 & 107 & 14.4 & 77 & 10.4 & 310 & 41.7 \\
\hline Several times a year & 44 & 5.9 & 79 & 10.6 & 125 & 16.8 & 59 & 7.9 & 307 & 41.3 \\
\hline Several times a month & 9 & 1.2 & 41 & 5.4 & 59 & 7.9 & 18 & 2.3 & 127 & 17.1 \\
\hline Total & 104 & 14.0 & 195 & 26.2 & 291 & 39.1 & 154 & 20.7 & 744 & 100.0 \\
\hline
\end{tabular}

Source: own research

$\mathrm{n}$ - number of cases; \% - percent of cases

and services, limit pollution and use resources in a rational manner, education on environmental protection and social responsibility did not have a positive influence in choosing European-based DIY oriented retail stores $\left(0.153^{\text {n.s. }}\right)$. This may be accounted for by the fact that either retailers did not educate consumers sufficiently about environmental governance, or that their measures were perceived by consumers as generally valid good practice - components of their general business strategies - and not as concrete actions performed to attract the regular consumer to the store. At the same time, it is possible that respondents just did not give enough credence to retailers' actions, associating them with promotion and/or communication campaigns, or viewing them as educational efforts.

The breakdown of results by generations revealed some characteristics and differences typical of each target segment, the present study hence contributing to a better practical understanding of generational theory. Baby Boomers chose green European-based DIY stores depending on the extent to which their strategies were in line with this generation's own sacrifices to protect the environment $\left(0.265^{*}\right)$ and social responsibility measures $\left(0.437^{* *}\right)$. The high strength of this dimension, coupled with the fact that the penchant for the rational use of resources and education on environmental protection and social responsibility did not have a significant influence on Baby Boomers' choice of green DIY stores justifies the belief that they had not been educated throughout their life to think about the impact on the environment of consuming various products. Environmental protection had never been a topic of interest for this generation. However, they now thought about the need to be in line with environmental protection and social responsibility measures, and were willing to make sacrifices to this effect. Thus, Baby Boomers seemed to have realized the need to protect the environment in the autumn of their life (Table 4).

Gen Xers exhibits a strong and favourable penchant for environmental protection $\left(0.370^{* *}\right)$ which actually determined their choice of environmentally oriented European-based DIY stores. The (financial) sacrifice entailed in the purchase of green products $\left(0.248^{* *}\right)$ was also a good enough reason to choose these green DIY stores. Although their behaviour did not show an active awareness, Gen Xers had a good education on

Table 4 Influences of DIY Store choice among consumer generations

\begin{tabular}{llclll}
\hline Effects & All generations & Baby Boomers & $X$ & Millennials $(Y)$ & $Z$ \\
\hline No of cases & 744 & 104 & 195 & 391 & $0.343^{* *}$ \\
EEP $\rightarrow$ Green DIY SC & $0.153^{\text {n.s. }}$ & $-0.131^{\text {n.s. }}$ & $0.117^{\text {n.s. }}$ & $0.171^{*}$ \\
PRUR $\rightarrow$ Green DIY SC & $0.180^{* *}$ & $0.223^{\text {n.s. }}$ & $0.370^{* *}$ & $0.087^{\text {n.s. }}$ & $0.191^{\text {n.s. }}$ \\
SPE $\rightarrow$ Green DIY SC & $0.262^{* * * *}$ & $0.265^{*}$ & $0.248^{* *}$ & $0.162^{*}$ & $0.495^{* *}$ \\
SRM $\rightarrow$ Green DIY SC & $0.210^{* * *}$ & $0.437^{* *}$ & $0.109^{\text {n.s. }}$ & $0.194^{* *}$ & $0.026^{\text {n.s. }}$ \\
\hline
\end{tabular}

Obs.: ${ }^{*} p<0.1 ;{ }^{* *} p<0.05 ;{ }^{* * *} p<0.01 ;{ }^{* * * *} p<0.001 ;$, ${ }^{\text {n.s. }}-$ insignificant

Fit indices General Model: $x^{2} / d f:$ 3.647; GFI (> 0.8): 0.925; AGFI (> 0.8): 0.902; NFI (> 0.8): 0.916; CFI (> 0.8): 0.940; TLI (>0.8): 0.928; SRMR ( $\left.\leq .08\right): 0.0448 ; R M S E A ~(\leq$ 0.08): 0.038;

Fit indices for Multigroup on generations: $X^{2} / d f: 1.912 ;$ GFI (>0.8): 0.887; AGFI (>0.8): 0.856; NFI (>0.8): 0.861; CFI (>0.8): 0.949; TLI (>0.8): 0.940; SRMR ( $\left.\leq 0.08\right)$ : $0.0737 ;$ RMSEA ( $\leq$ 0.08): 0.0350;

Source: own research 
environmental protection and social responsibility, being aware of the need to protect it and wishing to use green products only to the extent that their consumption did not have adverse effects on nature (Table 4).

For Millennials (Gen Y) the education on environmental protection and social responsibility $\left(0.343^{* *}\right)$ has a significant influence in making them choose green DIY stores, with an impact of high relationship strength and significance. Millennials also purchased from these stores because they were willing to make a financial sacrifice to protect the environment $(0.162 \%)$, and because the DIY stores implemented social responsibility measures $\left(0.194^{* *}\right)$. Education on environmental protection and social responsibility prompted them to take action, while their green orientation made them believe that, through their competencies, they had a share in protecting nature and reducing the consumption of resources (Table 4).

Generation $\mathrm{Z}$ is the target group for which the (financial) sacrifice needed to make a contribution to environmental protection was the most important dimension in their choice of green DIY retail stores $(0.495 \%)$. Zers seemed to be the most sensitive to "financial" issues, probably because they had modest incomes from seasonal employment and were financially dependent on their parents. As green European-based DIY stores (Table 3) were least visited by members of Generation Z, the results in Table 4 seem to confirm that, despite their education about the need to protect the environment $\left(0.171^{*}\right)$, they made limited use of it, as they were unlikely to frequently purchase products from DIY stores (Table 4).

\section{Conclusions}

From a theoretical perspective, this paper contributes to the literature on socially responsible consumption behaviour applied in retailing in an emerging market and the theory of reasoned action and generational theory. Consumers' orientation towards socially responsible consumption behaviour in a retail context, measured with the scale proposed by Antil and Bennett (1979) and Antil (1984) in reference to education on environmental protection and social responsibility, consumers' penchant for the rational use of resources, (financial) sacrifice to protect the environment underlies their preference for green European-based DIY stores by visiting them, purchasing from them and recommending them to peers. Thus, the paper combines socially responsible consumption behaviour with the theory of reasoned action, leading to a better understanding of the dimensions whereby these retailers may act on consumers, attract them into stores and influence their purchasing decisions.

The empirical research shows that each segment of consumers corresponding to a generation can be clearly delineated with respect to the values and elements influencing their behaviour towards the green DIY stores. Generational theory has a practical application in this case: Baby Boomers represent the generation that has realized, in the autumn of life, the need to protect the environment and be more socially responsible, and chooses green DIY stores depending on the extent to which personal sacrifice to protect the environment, as well as social responsibility measures, is in harmony with retailers' market strategy. Gen Xers prefer green DIY stores because they sell commodities enabling them to use resources in a rational way, and to bequeath a clean environment to future generations (their children). Millennials represent the generation educated in accordance with social responsibility and environmental protection principles and norms who choose green DIY stores according to which strategies for pollution reduction overlap with their own aspirations and perceptions. Generation $\mathrm{Z}$ is the one for which the choice of green DIY stores depends most on the financial sacrifice they have to make to this effect.

From a managerial perspective, this paper enables retailers operating in an emerging market to better understand the various consumer segments, herein represented by each generation, and to define a specific positioning strategy, together with a strategy for targeting and attracting these segments and gaining their loyalty. Moreover, retailers may consider the relevant dimensions typical of each generation in order to customize their offers, for example, offers at more attractive prices for Gen Z, or offers focused on saving resources and raw materials for Gen Xers.

One of the research limitations is the fact that consumer perception was examined only in an emerging market. Future research should make a comparison between saturated and emerging markets (Swoboda et al., 2017), while focusing on how the retail format is transferred from the home market to emerging markets (Swoboda et al., 2014). Consumer habits vary, and comparative analysis thereof could help establish an overall picture of the evolution of consumer preferences across generations.

Another limitation is the fact that the research did not make a comparison between respondents' domicile (urban versus rural), nor did it take into account the influence of income in the choice of retail format. More often than not, the money an individual has, and is willing to spend on shopping may influence the choice of the store about to be visited. Undoubtedly, another limitation of the research is the relatively small sample covered, so that the research findings cannot be generalized to the entire population. Moreover, the research did not consider the differences between the members of a group. For example, Gen $\mathrm{Z}$ members have many heterogeneous characteristics, so that the findings for the sample considered cannot be extended to all persons in the same category.

Future studies should also focus on investigating consumer perceptions towards green issues in other 
retail formats, such as fashion, grocery, etc., and should highlight, for example, whether consumer preference and involvement therein is stronger than in DIY retail. Likewise, any future research should consistently track retailers' communication of social responsibility measures, as well as the extent to which the prices of products vary according to their contribution to pollution reduction. Future analyses should pursue the extent to which retailers constantly keep an eye on environmental governance through the actions they carry out throughout the value chain.

\begin{abstract}
Abbreviations
AGFI (Fit index of a structural equation model): adjusted goodness of fit index; AMOS: Structural Equation Modelling software; Baby Boomers: people born between 1946 and 1964; CFI (Fit index of a structural equation model): comparative fit index; df: Degrees of freedom; DIY (Retail): Do-lt-Yourself (Retail); EEP: Education on environmental protection and social responsibility; EV: Eigenvalues for each factor; Gen Xers or X: People born between 1965 and 1979; Gen Y or Y or Millennials: People born between 1980 and 1994; Gen Z or Z: People born between 1994 and 2000; GFI (Fit index of a structural equation model): Goodness of fit index; KMO: Kaiser-Meyer-Ohlin criterion; NFI (Fit index of a structural equation model): Normed fit index; p: Probability; PRUR: Penchant for rational use of resources; RMSEA (Fit index of a structural equation model): Root mean square error of approximation; SC: Store Choice; SPE: Sacrifice for the sake of environmental protection; SRM: Social responsibility measures; SRMR (Fit index of a structural equation model): Standardised root mean square residual; TLI (Fit index of a structural equation model): TuckerLewis fit index; var: Variance; X or Gen Xers: People born between 1965 and 1979; Y or Millennials or Gen Y: People born between 1980 and 1994; Z or Gen Z: People born between 1994 and 2000; a: Cronbach's a coefficient (checking data reliability); $x^{2}: H i$ square
\end{abstract}

\section{Acknowledgements}

The author would like to thank to Associate Prof. Raluca Babut, PhD, member of the research grant CNCS - UEFISCDI, project number PN-II-RUTE-2014-4-0312 who contributed with her experience and knowledge and gave some critical views regarding the manuscript and the structure of the article. The author also thanks Liz Hollis from UK for making the proof read of the article. The author also thanks to the volunteers who administered the questionnaire and helped collecting the data.

\section{Funding}

"This work was supported by a grant of the Romanian National Authority for Scientific Research and Innovation, CNCS - UEFISCDI, project number PN-IIRU-TE-2014-4-0312". The author of the article is the principal investigator of the project financed by CNCS - UEFISCDI. The author designed this article, collected the data, made the analysis and the interpretation of data and wrote the manuscript.

\section{Availability of data and materials}

The data was collected by face to face interviews during 2016. The collection of data was supported by a research grant of the Romanian National Authority for Scientific Research and Innovation, CNCS - UEFISCDI, project number PN-II-RU-TE-2014-4-0312". The author of this article was principal investigator (project leader) of the project. The coauthor of the article was a research assistant on the project.

\section{Authors' contributions}

The authors of the paper have the entire contribution to the paper. DCD is responsible for the methodological part and the results analysis and interpretation, as where BMB is responsible mainly for the literature review. DCD also assumed the final shape and the submission of the article. All authors read and approved the final manuscript.

\section{Author's information}

Dan-Cristian Dabija* (corresponding author), Associate Prof. Dr. with Habilitation (PhD Supervision), Babeș-Bolyai University, Cluj-Napoca, Romania,
Faculty of Economics and Business Administration, Teodor Mihali 58-60, RO - 400,591 Cluj-Napoca, Romania, Room 125, Tel. 0040.264.418.652/3/4/5; Fax. 0040.264.412.570, Department of Marketing, cristian.dabija@econ.ubbcluj.ro Dan-Cristian Dabija, PhD, is Associate Professor at the Department of Marketing and PhD Supervisor in Marketing at the PhD School in Business and Economics of the Faculty of Economics and Business Administration, Babeș-Bolyai University, Romania. Dr. Dabija completed his PhD Studies at the Bucharest University of Economic Studies, Romania, and has been awarded several doctoral and postdoctoral research scholarships at Romanian, German, British and Finish universities. Dr. Dabija has recently lead a research project on sustainability in retailing financed by the Romanian National Authority for Scientific Research and Innovation (125,000 EUR). He has published in various journals, has participated in numerous conferences (European Marketing Academy Conference, World Marketing Congress, Annual MBAA International Conference, Annual North American ACR Conference, RESER), and serves as an ad-hoc reviewer for Amfiteatru Economic, Journal of Cleaner Production, Journal of Marketing Management, Journal of Global Marketing, and Marketing Education Review, as well as for Romanian and European research projects. His teaching disciplines are Retailing, International Marketing, Tourism Marketing, Sales Promotion and Strategic Marketing. Dr. Dabija has conducted different trainings on project management, retailing, retail marketing, marketing, sales and promotions in summer schools, companies and human resources development courses. More recently Dr. Dabija published in Romanian the second edition of the book To conceive, to write and to publish a scientific article in business and economics, which was awarded in late 2017 the first book prize of the Romanian Association of Economic Faculties.

Brîndușa Mariana Bejan is PhD student since 2016 in Marketing at the PhD School in Business and Economics of the Faculty of Economics and Business Administration, Babeș-Bolyai University, Romania. The PhD thesis is about self-esteem and the influence on consumer behavior. Recently, PhD Bejan was Research Assistant and member in the project "Causal relationships between sustainable development and Generations $X$, respectively $Y$ in contemporary society. A holistic retail marketing approach". She has published in various journals and has participated in some conferences (Marketing from Information to Decision Cluj-Napoca, iCOnEc).

Brîndușa Mariana Bejan, PhD Student, Babes-Bolyai University, Cluj-Napoca, Romania, Faculty of Economics and Business Administration, Teodor Mihali 58-60, RO - 400,591 Cluj-Napoca, Romania, Room 125, Tel. 0040.264.418.652/ 3/4/5; Fax. 0040.264.412.570, Department of Marketing,

brandusa.bejan@econ.ubbcluj.ro

\section{Competing interests}

The authors declare that they have no competing interests

\section{Publisher's Note}

Springer Nature remains neutral with regard to jurisdictional claims in published maps and institutional affiliations.

Received: 8 May 2018 Accepted: 10 August 2018

Published online: 03 September 2018

\section{References}

Aaker, D., Kumar, V., \& Day, G. (2000). Marketing research (7th ed.). New York: John Wiley \& Sons, Inc..

Acar, A. (2014). Do intrinsic and extrinsic motivation factors differ for generation $X$ and generation Y? Int J Bus Soc Sci, 5(5), 12-20.

Ajzen, l., \& Fishbein, M. (1980). Understanding attitudes and predicting social behaviour. Englewood Cliffs, NJ: Prentice Hall.

Antil, J. A. (1984). Socially responsible consumers: Profile and implications for public policy. Journal of Macromarketing, 4(2), 18-39.

Antil, J. A., \& Bennett, P. D. (1979). Construction and validation of a scale to measure socially responsible consumption behaviour. In K. H. Henion II \& T. C. Konnear (Eds.), The conserver society (pp. 51-68). Chicago: American Marketing Association.

Aschemann-Witzel, J., \& Zielke, S. (2017). Can't buy me green? A review of consumer perceptions of and behavior toward the price of organic food. The Journal of Consumer Affairs, 51(1), 211-251.

Ayadi, N., \& Lapeyre, A. (2016). Consumer purchase intentions for green products: Mediating role of WTP and moderating effects of framing. J Mark Commun, 22(4), 367-384. 
Baumgartner, R., \& Rauter, R. (2016). Strategic perspectives of corporate sustainability management to develop a sustainable organization. J Clean Prod, 140, 81-92 (2016).. https://doi.org/10.1016/j.jclepro.2016.04.146.

Bear, S. E. (2017). Organic delights: Examining the challenges of corporate social responsibility. Management Teaching Review, 2(2), 98-106.

Bekele, A., Bosona, T., Nordmark, I., Gebresenbet, G., \& Ljungberg, D. (2012). Assessing the sustainability of food retail business: The case of Konsum Varmländ, Sweden. Journal of Service Science and Management, 5, 373-385.

Biswas, A., \& Roy, M. (2015). Green products: An exploratory study on the consumer beaviour in emerging economies of the east. J Clean Prod, 87, 463-468.

Boschini, A. (2015). Boomers, Millennials are more similar than you think. Home Accents Today, 44. http://www.homeaccentstoday.com/blogpost/13762boomers-millennials-are-more-similar-you-think.

Chu, P.-Y., Lin, Y.-L., \& Chi, W.-N. (2013). A study of consumers' willingness to pay for environmentally friendly clothing for generation $Y$ : The influences of shopping orientation, fashion orientation and green consumption style. Marketing Review, 10(1), 19-42.

Churchill, G. A. (1991). Marketing Research: Methodological Foundation (5th ed.). Fort Worth: The Dryden Press.

Codrington, G. (2008). Detailed Introduction to Generational Theory. Tomorrow Today, 1-16. http://ngkok.co.za/sinode2016/intro-generations.pdf.

Cordeiro, H. T., \& de Albuquerque, L. G. (2017). Career profiles of generation $Y$ and their potential influencers. Brazilian Administration Review, 14(3), 2-21.

Dabija, D. C., Pop, N. A., \& Szentesi, S. (2014). A customer-oriented perspective on retail brand equity in the fashion industry. Industria Textilă, 65(1), 37-46.

Dabija, D. C., \& Abrudan, I. N. (2015). Retailing in Romania: From statist to nearly capitalist. European Retail Research, 27(2), 55-92.

Dabija, D. C., \& Băbuț, R. (2013). An approach to sustainable development from Tourist's perspective. Empirical evidence in Romania. Amfiteatru Economic, 15(7), 617-633

Dabija, D. C., \& Pop, C. M. (2013). Green marketing - Factor of competitiveness in retailing. Environ Eng Manag J, 12(2), 393-400.

Dabija, D. C., \& Bejan, B. M. (2017). Behavioral antecedents for enhancing green customer loyalty in retail. In R. Pamfilie, V. Dinu, L. Tăchiciu, D. Pleșea, \& C. Vasiliu (Eds.), BASIQ international conference: New trends in sustainable business and consumption (Vol. 1, pp. 183-191). Bucharest: Editura ASE.

Dabija, D.C., Băbuț, R., Dinu, V., Lugojan, M., (2017). Cross-generational analysis of information searching based on social media in Romania. Transformations in Business \& Economics, 16(2(41)), 248-270.

Dabija, D. C., Bejan, B. M., \& Tipi, N. (2018). Generation X versus Y communication behavior on social media when purchasing food versus touristic services. Ekonomie a Management (E\&M) / Economics and Management, 21(1), 191-205.

Dabija, D. C. (2018). Enhancing green loyalty towards apparel retail stores: A cross-generational analysis on an emerging market. Journal of Open Innovation: Technology, Market, and Complexity, 4(1), 1-8.

Dedeman.ro. (2016). Press release. http://https://www.dedeman.ro/spaw2/ uploads/files/comunicat-de-presa-raspuns-scrisoare-de-clic-ro.pdf. Accessed 20 Jan 2017.

Dermody, J., Hanmer-Lloyd, S., Koenig-Lewis, N., \& Lifen Zhao, A. (2015) Advancing sustainable consumption in the UK and China: The mediating effect of pro-environmental self-identity. J Mark Manag, 31(13-14), 1472-1502.

Desai, S. P., \& Lele, V. (2017). Correlating internet, social networks and workplace a case of generation Z students. Journal of Commerce \& Management Thought, 8(4), 802-815.

Elg, U., \& Hultman, J. (2011). Retailers` management of corporate social responsability (CSR) in their supplier relationship - does practice follow best practice? Int Rev Retail Distrib Consum Res, 21(5), 445-460.

Forza, C., \& Filippini, R. (1998). TQM impact on quality conformance and customer satisfaction: A causal model. Int J Prod Econ, 55(1), 1-20.

French, S., \& Showers, L. (2008). Consumer lifestyles of health and sustainability. Research Review, 15(1), 31-34.

Galbreth, M. R., \& Ghosh, B. (2012). Competition and sustainability: The impact of consumer awareness. Decis Sci, 44(1), 127-159.

Green, K. W., Toms, L. C., \& Clark, J. (2015). Impact of market orientation on environmental sustainability strategy. Management Research Review, 38(2), 217-238.

Gurtoo, A., Sarup, V., \& Williams, C. C. (2010). Explaining the do-it-yourself (DIY) retail market in a developing country: Preliminary lessons from India. Int Rev Retail Distrib Consum Res, 20(3), 335-351.
Hill Hyun-Hwa Lee, J. (2012). Young generation Y consumers' perceptions of sustainability in the apparel industry. Journal of Fashion Marketing and Management: An International Journal, 16(4), 477-491.

Homburg, C., \& Krohmer, H. (2006). Marketingmanagement, Strategie - Instrumente - Umsetzung - Unternehmensführung, Ediţia a doua. Wiesbaden: Gabler.

Honeywell, J., \& Pease, B. (2014). Leveraging generational differences for sustainability success. In Environmental Design \& Construction (pp. 22-24).

Hubbard, G. (2009). Measuring organizational performance: Beyond the triple bottom line. Bus Strateg Environ, 19(8), 177-191.

Joshi, Y., \& Rahman, Z. (2015). Factors affecting green purchase behavior and future research directions. International Strategic Management Review, 3(1-2), $128-143$.

Ju, T. L., Lin, B., Lin, C., \& Kuo, H. J. (2006). TQM critical factors and KM value chain activities. Total Qual Manag, 17(3), 373-393.

Katz, S. (2017). Generation X: A critical sociological perspective. GENERATIONS Journal of the American Society on Aging, 41(3), 12-19.

Lakshmi, V. R., \& Kennedy, H. (2017). The role of business sustainability in human resource management: A study on Indian manufacturing company. The South East Asian Journal of Management, 11(1), 70-85.

Laroche, M., \& Bergeron, J. (2001). Targeting consumers who are willing to pay more for environmentally friendly products. J Consum Mark 18(6), 503-520.

Li, Y., Lu, Y., Zhang, X., Liu, L., Wang, M., \& Jiang, X. (2016). Propensity of green consumption behaviours in representative cities in China. J Clean Prod, 133, 1328-1336.

Lim, W. M. (2017). Inside the sustainable consumption theoretical toolbox: Critical concepts for sustainability, consumption, and marketing. Journal of Business Research, 78, 69-80.

Lin, J., Lobo, A., \& Leckie, C. (2017). The role of benefits and transparency in shaping consumers' green perceived value, self-brand connection and brand loyalty. J Retail Consum Serv, 35, 133-141.

Madden, T. J., Ellen, P. S., \& Ajzen, I. (1992). A comparison of the theory of planned behavior and the theory of reasoned action. Personality and Social Pshychology Bulletin, 18(1), 3-9.

Marsh, H. W. (1998). Pairwise deletion for missing data in structural equation models: Nonpositive definite matrices, parameter estimates, goodness of fit, and Adjusted Sample Sizes. Structural Equation Modeling: A Multidisciplinary Journal, 5(1), 22-36.

Meriac, J. P., Woehr, D. J., \& Banister, C. (2010). Generational differences in work ethic: An examination of measurement across three cohorts. J Bus Psychol, 25(2), 315-324.

Mulder, K. F. (2017). Strategic competences for concrete action towards sustainability: An oxymoron? Engineering education for a sustainable future. Renew Sust Energ Rev, 68, 1106-1111.

Nadlifatin, R., Lin, S.-C., Rachmaniati, Y., Persada, S., \& Razif, M. (2016). A proenvironmental reasoned action model for measuring citizens' intentions regarding Ecolabel product usage. Sustainability, 8(11), 1165.

Nasir, V. A., \& Karakaya, F. (2014). Underlying motivations of organic food purchase intentions. Agribusiness, 30(3), 290-308.

Nuttavuthisit, K., \& Thøgersen, J. (2015). The importance of consumer Trust for the Emerge of a market for green products: The case of organic food. J Bus Ethics, 140(2), 323-337.

Obucina, V. (2017). Romania shows fast economic growth after 10 years in the EU. https://financialobserver.eu/cse-and-cis/romania/romania-shows-fasteconomic-growth-after-10-years-in-eu/. Accessed 20 Jan 2017.

Praktiker.ro. (2015). Reciclează ce nu mai funcționează! https://www.praktiker.ro/ media/pdfs/csr/c5a07-Pliant-Informare-Utilizatori-EEE_RoRec_tipar_C.PDF. Accessed 20 Jan 2017.

Pryshlakivsky, J., \& Searcy, C. (2015). A heuristic model for establishing trade-offs in corporate sustainability performance measurement systems. J Bus Ethics, 144(2), 323-342.

Resurse Terra (2017). Earth's 2017 resource 'budget' spent by August 2: report. https://phys.org/news/2017-08-earth-resource-spent-august.html. Accessed 20 Jan 2017.

Rettie, R., Burchell, K., \& Riley, D. (2012). Normalising green behaviours: A new approach to sustainability marketing. J Mark Manag, 28(3-4), 420-444.

Romani, S., Grappi, S., \& Bagozzi, R. P. (2016). Corporate socially responsible initiatives and their effects on consumption of green products. J Bus Ethics, 135, 253-264.

Schmidt, A., Ferraro, T., \& Phillips, D. (2012). Film festival - sustainability: A new consumer movement. Adv Consum Res, 38, 718-720. 
Schuler, D., Rasche, A., Etzion, D., \& Newton, L. (2017). Corporate sustainability management and environmental ethics. Bus Ethics Q, 27(2), 213-237.

Shobeiri, S., Rajaobelina, L., Durif, F., \& Boivin, C. (2016). Experiential motivations of socially responsible consumption. Int J Mark Res, 58(1), 119-139.

Silva Braga, J. S., da Silva, D., Gabriel, M. L., \& de Oliveira Braga, W. R. (2015). The effects of environmental concern on purchase of green products in retail. Procedia - Social and Behavioral Sciences, 170, 99-108.

Singh, S., \& Sharma, A. (2016). An empirical investigation on demographics and socially responsible consumption behavior in Delhi. Pranjana: The Journal of Management Awareness, 19(1), 44-50.

Smith, K. (2010). An examination of marketing techniques that influence Millennials' perceptions of whether a product is environmentally friendly. J Strateg Mark, 18(6), 457-470.

Swoboda, B., Berg, B., \& Dabija, D. C. (2014). International transfer and perception of retail formats: A comparison study in Germany and Romania. Int Mark Rev, 31(2), 155-180.

Swoboda, B., Morbe, L., \& Dabija, D. C. (2017). International transfer and perception of retail formats - An inter- and intra-format comparison study in Germany, France and Romania. Marketing ZFP - Journal of Research and Management, 39(4), 24-36.

Taken Smith, K. (2014). Millennials` interpretations of green terminology. Academy of Marketing Studies Journal, 18(1), 55-68.

Tariq, M. Z. (2014). Impact of green advertisement and green brand awareness on green satisfaction with mediating effect of buying behavior. Journal of Managerial Sciences, 8(2), 274-289.

Tuten, T. (2013). Promoting sustainability by marketing green products to nonadopters. Gestion 2000, 30(2), 93-102.

Ulusoy, E. (2016). Experiential responsible consumption. J Bus Res, 69(1), 284-297.

Williams, K., \& Page, R. (2011). Marketing to the generations. Journal of Behavioral Studies in Business, 3, 1-17.

Zahari, A. R., \& Esa, E. (2016). Motivation to adopt renewable energy among generation Y. Procedia Economics and Finance, 35, 444-453.

\section{Submit your manuscript to a SpringerOpen ${ }^{\circ}$ journal and benefit from:}

- Convenient online submission

- Rigorous peer review

- Open access: articles freely available online

- High visibility within the field

- Retaining the copyright to your article

Submit your next manuscript at $\boldsymbol{\nabla}$ springeropen.com 